\title{
Synoptic Analysis of a Heavy Rainfall Event over Southeast Region of Bangladesh Using WRF Model
}

\author{
M. N. Ahasan ${ }^{1 *}$, K. M. Z. Rayhun ${ }^{2}$, M. A. Mannan ${ }^{1}$, and S. K. Debsarma ${ }^{1}$ \\ ${ }^{1}$ SAARC Meteorological Research Centre (SMRC), Dhaka, Bangladesh \\ ${ }^{2}$ Department of Physics, Jahangirnagar University, Dhaka, Bangladesh
}

Received 21 December 2012, accepted in final revised form 25 July 2013

\begin{abstract}
Synoptic analysis of the heavy rainfall event of 7 September 2011 was carried out using the Weather Research and Forecasting (WRF) Model. This extraordinary rainfall event was localized over the southeast region of Bangladesh and recorded rainfall was $331 \mathrm{~mm}$ at Chittagong and $226 \mathrm{~mm}$ at Sandwip within a span of 24-h. The model was run at $9 \mathrm{~km}$ horizontal resolution using KF CPS with YSU PBL scheme. The model performance was evaluated by examining the different predicted parameters like mean sea level pressure, upper and lower level circulations, wind shear, relative vorticity, convergence, moisture and rainfall. The rainfall was validated with TRMM 3B42RT and observed rainfall data. The results indicate that the WRF model was able to simulate the heavy rainfall event, and associated synoptic features reasonably well, though there are some biases in the rainfall pattern. The results suggest that the highly localized heavy rain over southeast Bangladesh was the result of an interaction of the large scale monsoon system with cyclonic disturbances and required moisture have been supplied from the Bay of Bengal. The low level flow facilitated strong convergence over the region due to horizontal wind shear, which resulted in maintenance of the storms.
\end{abstract}

Keywords: Heavy Rainfall; WRF Model; Simulation; Validation; TRMM.

(C) 2013 JSR Publications. ISSN: 2070-0237 (Print); 2070-0245 (Online). All rights reserved.

doi: http://dx.doi.org/10.3329/jsr.v5i3.13171 $\quad$ J. Sci. Res. 5 (3), 421-434 (2013)

\section{Introduction}

Bangladesh $\left(20^{\circ} 34^{\prime}-26^{\circ} 38^{\prime} \mathrm{N}\right.$ and $\left.88^{\circ} 01^{\prime}-92^{\circ} 41^{\prime} \mathrm{E}\right)$ is situated at the interface of two different environments, with the Bay of Bangal to the South and Himalayas to the north. The entire area of Bangladesh is about 1, 47,570 sq. $\mathrm{km}$ [1]. It lies at the bottom of the Ganges-Bhramaputra-Meghna (GBM) catchments. The central parts of the country are mostly flat alluvial plains, rising to the northeast and north to meet the Khasi-JaintiaGaro hills complex and the plateau of Shillong. The topography is hilly in the southeast on the western slopes of Mizo hills and Arakan Mountains [2].

* Corresponding author: nazmul_smrc@yahoo.com 
A low pressure area formed over the land near Orissa and neighbourhood on 6 September 2011. It moved mainly westwards across central part of India and then less marked over west Rajasthan on 14th September 2011 [3].

On 7 September 2011 , Chittagong $\left(22.35^{\circ} \mathrm{N}, 91.82^{\circ} \mathrm{E}\right)$, is the coastal city of Bangladesh was recorded $331 \mathrm{~mm}$ (13.03 in) rainfall in 24 hours. Sandwip $\left(22.48^{\circ} \mathrm{N}\right.$, $91.43^{\circ} \mathrm{E}$ ), is an isolated island of Bangladesh. It is nearly $43 \mathrm{~km}$ from Chittagong and 79 $\mathrm{km}$ from Hatiya was recorded $226 \mathrm{~mm}$ (8.90 in) rainfall in 24 hours [4]. Spatial distribution of observed rainfall over Bangladesh on 7 September 2011 is shown in Fig. 1.

Heavy rainfall events become significant in human affairs when they are combined with other hydrological elements. The problem of forecasting heavy precipitation is specially difficult since it involves creating a quantitative precipitation forecast, recognized as a challenging task [5]. Simulation of active mesoscale systems such as western disturbances, severe thunderstorms, tropical cyclones and heavy rainfall episodes during active monsoon season, with high-resolution mesoscale models such as the Fifth-Generation NCAR/Penn State Mesoscale Model (MM5) and Weather Research and Forecasting (WRF) model have been attempted by many researchers (e.g., Ahasan et al. [6]; Kumer et al. [7]; Dev et al. [8]; Patra et al. [9], Prasad [2]; Das [10, 11], and Litta et al. [12]). Application of numerical weather prediction (NWP) model in research and forecasting of heavy rainfall during monsoon season is very little in Bangladesh. However, some works have been done to investigate the synoptic features responsible for occurring the heavy rainfall activities during monsoon season over Bangladesh using NWP model by Prasad [2]; Das et. al. [13] and Ahasan et al. [14].

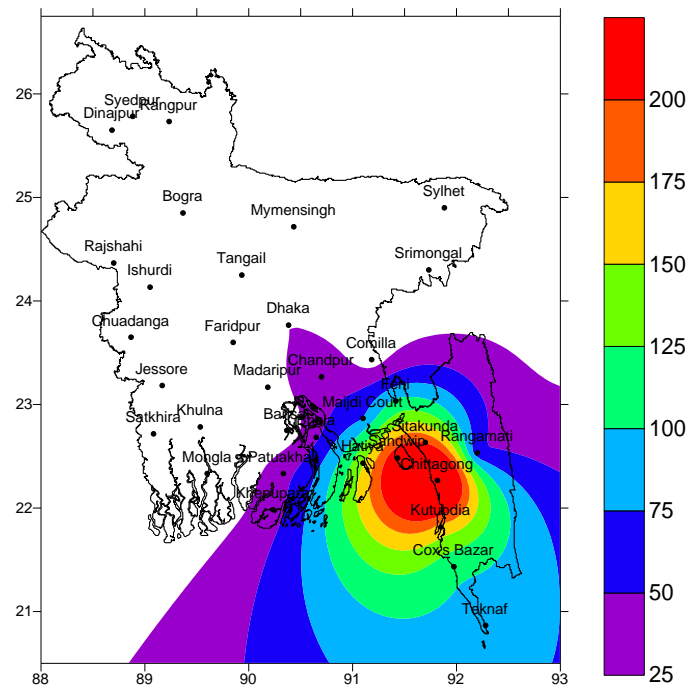

Fig. 1. Spatial distribution of rainfall over Bangladesh on 7 September 2011. BMD recorded $331 \mathrm{~mm}$ (13.03 in) rainfall at Chittagong and $226 \mathrm{~mm}$ (8.90 in) rainfall at Sandwip in 24 hours on 7 September 2011. 
The primary objective of this study is to identify and document the possible synoptic and environmental characteristics of the heavy rainfall events of 7 September 2011 over southeast coastal region of Bangladesh. The secondary objective is to test the performance of the WRF model to simulate the selected rainfall event.

\section{Model Introduction, Model Experimental Setup, Data Used and Methodology}

\subsection{Model introduction}

The Weather Research and Forecasting (WRF) model (Version 3.2.1, release August 2010) has been used to carry out the present study. The WRF Model is a new-generation mesocale Numerical Weather Prediction (NWP) system designed to serve both operational forecasting and atmospheric research needs. It features multiple dynamical cores, a 3-dimensional variational (3DVAR) data assimilation system, and a software architecture allowing for computational parallelism and system extensibility. WRF is suitable for a broad spectrum of applications across scales ranging from meters to thousands of kilometers. Applications of WRF include research and operational numerical weather prediction (NWP), data assimilation and parameterized-physics research, downscaling climate simulations, driving air quality models, atmosphereocean coupling, and idealized simulations (i.e., boundary-layer eddies, convection, baroclinic waves). There are two dynamics solvers in the WRF system: the Advanced Research WRF (ARW) dynamic solver (originally referred to as the Eulerian mass or "em") developed primarily at NCAR, and the NMM (Nonhydrostatic Mesoscale Model) solver developed at NCEP. The ARW system consists of the ARW dynamics solver with other components of the WRF system needed to produce a simulation. The WRFARW (Version 3.2.1) has been implemented during the present study.

\subsection{Model experimental setup}

The WRF model is run on single domain at $9 \mathrm{~km}$ horizontal resolution. The domain size is taken $117 \times 134 \mathrm{~km}$. The domain is centered $\left(23.50^{\circ} \mathrm{N}, 90.00^{\circ} \mathrm{E}\right)$ over Dhaka, Bangladesh to represent the regional-scale circulations and to solve the complex flows in this region. The configuration of this domain is shown in Fig. 2. There are 27 vertical layers. The model is run using the Kain-Fritsch (new Eta) scheme for cumulus parameterization, Yonsei University (YSU) scheme for the boundary layer parameterization, WSM 3 class Simple Ice schemes for microphysics and RRTM for longwave and Dudhia for short wave radiation scheme for the selected case. The physics and dynamics employed in the model for the present study are summarized in Table 1. The initial condition of the model simulation is taken as 0000 UTC of 06 September 2011 (about 48-h before of the event). 


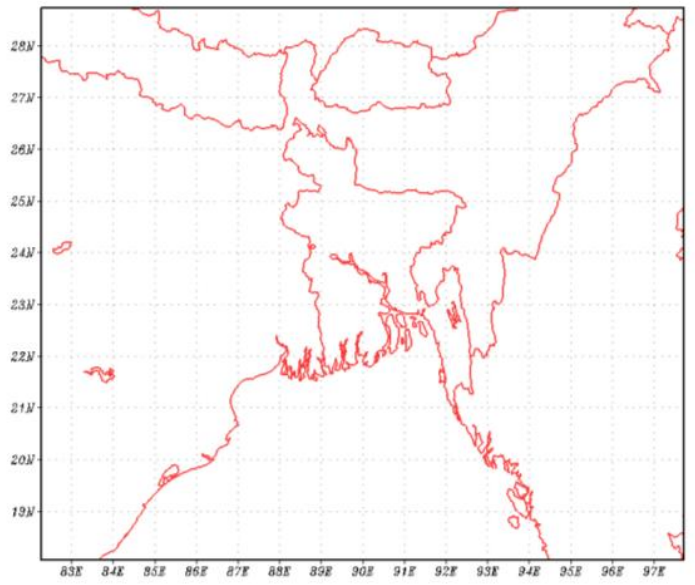

Fig. 2. WRF Model domain.

Table 1. Physics and dynamics used in the WRF model.

\begin{tabular}{ll}
\hline & \multicolumn{1}{c}{ Physics } \\
\hline Convection & Kain-Fritsch (new Eta) [15] \\
PBL & YSU scheme [16] \\
Surface layer option & Monin-Obukhov \\
Cloud Microphysics & WSM 3-Class simple Ice \\
Radiation & RRTM [17] long wave and Dudhia [18] short wave \\
Land surface processes & Unified Noah Land Surface Model \\
\hline & \multicolumn{1}{c}{ Dynamics } \\
\hline Time integration & 3rd order Runge-Kutta \\
Time steps & 60 m \\
Vertical differencing & Arakawa's energy conserving scheme \\
Time filtering & Robert's method \\
Horizontal diffusion & 2nd order over quasi-pressure, surface, scale selective \\
Spatial difference scheme & 6th order centered difference \\
Horizontal grid & Arakawa C-grid \\
\hline
\end{tabular}

\subsection{Data used}

The United States Geological Survey (USGS) Global datasets with 30sec horizontal resolution were used to create terrain and land-use field. The Final (FNL) Global Model 
Tropospheric data of NCEP with the $1^{\circ} \times 1^{\circ}$ resolution were used as the initial and lateral boundary condition.

The daily $0.25^{\circ} \times 0.25^{\circ}$ resolution TRMM 3B42RT rainfall data have been downloaded from website of NASA [19] to justify the model simulated rainfall structure, development time and location. The daily observed rainfall data have been collected from the archive of Bangladesh Meteorological Department (BMD) to compare or validate the model output. The Meteosat- 5 cloud images are also used to see the signature of cloud activities and moisture presence over the study area.

\subsection{Methodology}

The model outputs help to investigate the synoptic and environmental characteristics for the event. The mean sea level pressure, low level and upper level wind flow, horizontal and vertical profile of moisture flux, low level relative vorticity, vertical wind shear of $u$ component of wind, convective available potential energy, convective inhibition energy and rainfall etc fields have been investigated. The high amount of rainfall occurred during the end of the day. Thus all synoptic maps are prepared for the 2100 UTC (peak time of heavy rainfall spell) of 7 September 2011. Observed daily rainfall data of BMD and daily TRMM 3B42RT rainfall data have been used to validate / compare the model simulated rainfall. Both spatial and temporal comparison methods have been used to compare the model simulated rainfall with observed rainfall.

\section{Results and Discussion}

The Weather Research and Forecasting (WRF) model Version 3.2.1 has been used to investigate the possible causes and mechanisms behind the maintenance of heavy rainfall event over Bangladesh during southwest summer monsoon season. Figs. 3 to 13 contain the analyses of various synoptic maps of the flow variables and some derived parameters at map time 2100 UTC of 7 September 2011. The results are described in the following section in details.

\section{(a) Mean sea level pressure and $10 \mathrm{~m}$ height wind}

The mean sea level pressure $(\mathrm{hPa})$ and $10 \mathrm{~m}$ height wind $\left(\mathrm{ms}^{-1}\right)$ at $2100 \mathrm{UTC}$ of 07 September 2011 is shown in Fig. 3. It is found that a well marked low pressure area formed over the Gangetic West Bengal of India and nearby territory of Bangladesh. The isobars over the North Bay of Bengal have almost north south run which enhance the moisture feeding into country. It is found from the $10 \mathrm{~m}$ height wind field that the southwesterly low level flow (LLF) are moving towards the southeast coastal region of Bangladesh where heavy rainfall had observed. This LLF from the large area of the Bay of Bengal moves towards the country and convergences over a narrow belt of the southeast coastal region of Bangladesh where heavy rainfall was reported. The poleward meridional component of wind injects moisture from the Bay of Bengal into southeast 
region of Bangladesh. These are the very common synoptic conditions for convective activities over southeast Bangladesh.

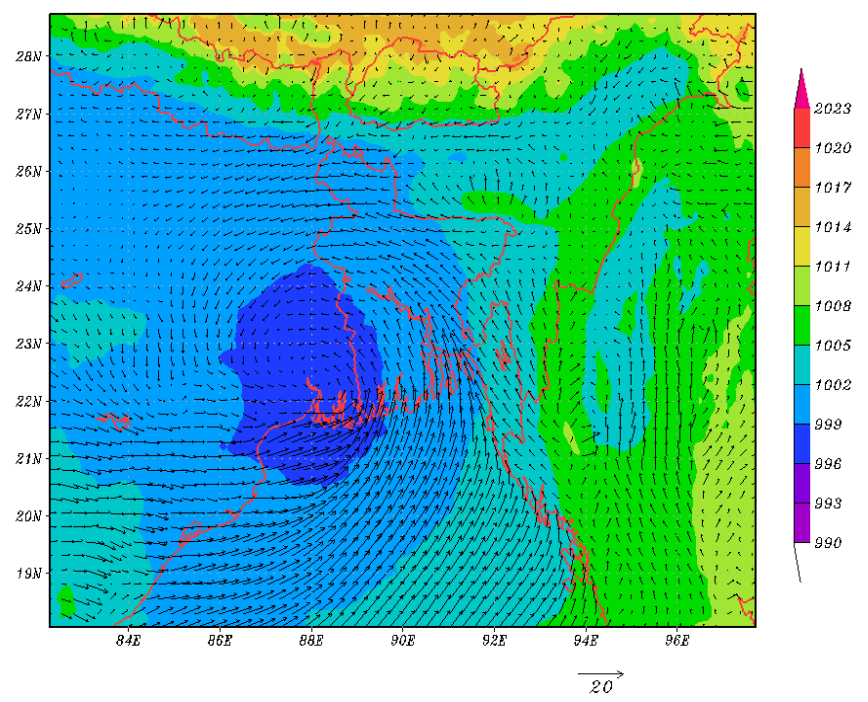

Fig. 3. Mean sea level pressure (shading) and $10 \mathrm{~m}$ height wind (arrow) analysis at 2100 UTC of 07 September, 2011.

\section{(b) Mid level (500 hPa) and upper level (350hPa) wind}

The distribution of model simulated mid-level wind at $500 \mathrm{hPa}$ and upper level wind at $350 \mathrm{hPa}$ valid for 2100 UTC of 7 September 2011 are presented in Fig. 4(a-b). It is found that the low pressure area which observed in low level wind (Fig. 3) is persistent upto the mid-level $(500 \mathrm{hPa})$ of the troposphere. The outflow of wind is observed at upper level wind at $350 \mathrm{hPa}$ (Fig. 4(b)).
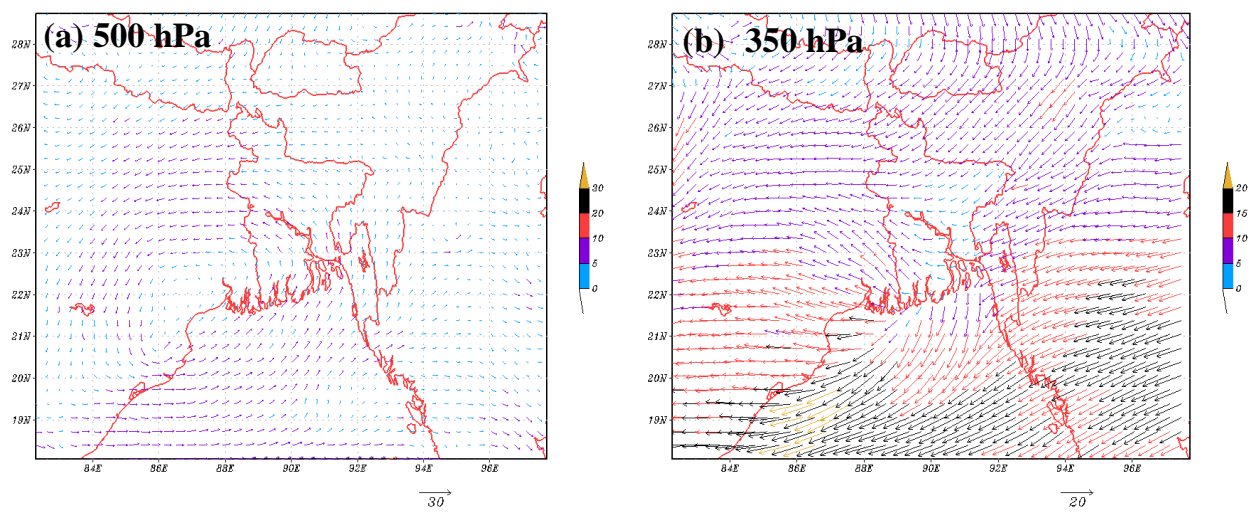

Fig. 4. Model simulated mid level and upper level wind $\left(\mathrm{ms}^{-1}\right)$ analysis valid for 2100 UTC on 7 September 2011 at $500 \mathrm{hPa}$ (a) and $350 \mathrm{hPa}(\mathrm{b})$. 


\section{(c) Vertical wind shear of the u component of wind}

Vertical wind shear $\left(\mathrm{ms}^{-1}\right)$ of the $\mathrm{u}$ component of wind in the lowest $6 \mathrm{~km}$ of the atmosphere 500-925 hPa valid for 2100 UTC of 07 September 2011 is shown in Fig. 5. It is found that the environment of southeast coastal region of Bangladesh and neighbourhoods are characterized by a comparatively stronger vertical wind shear. A core of vertical wind shear of the order of $5-10 \mathrm{~ms}^{-1}$ in the region of southeast Bangladesh and neighbourhood is clearly seen. Only single cell thunderstorm may be expected to form in the environment having this type of low vertical wind shear $(>10$ $\left.\mathrm{ms}^{-1}\right)$.

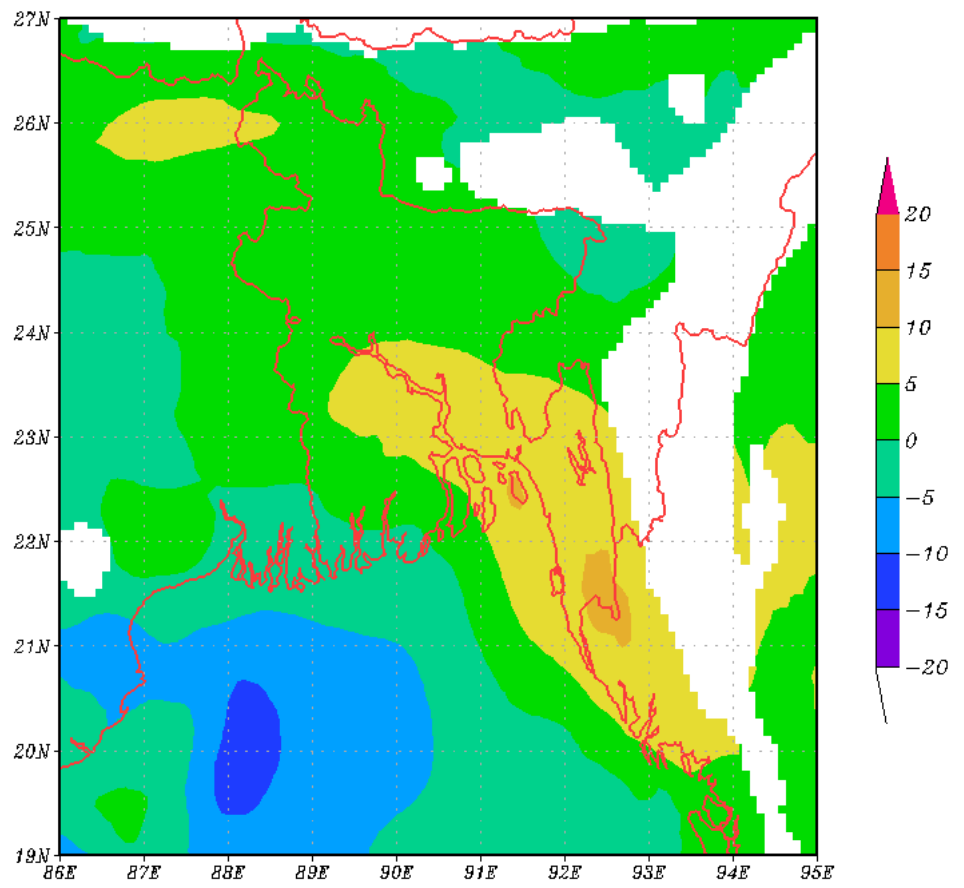

Fig. 5. Vertical wind shear $\left(\mathrm{ms}^{-1}\right)$ of the $\mathrm{u}$ component of wind in the lowest $6 \mathrm{~km}$ of the atmosphere at 500-925 hPa valid for 2100 UTC of 7 September 2011.

\section{(d) Low level relative vorticity}

The low level relative vorticity field at 2100 UTC on 7 September 2011 is presented in Fig. 6. The relative vorticity field shows strong vorticity over southwest part of the country and neighbourhoods. The vorticity field is generated obviously due to the horizontal shear in the meridional wind flow as there is no curvature in the stream. 


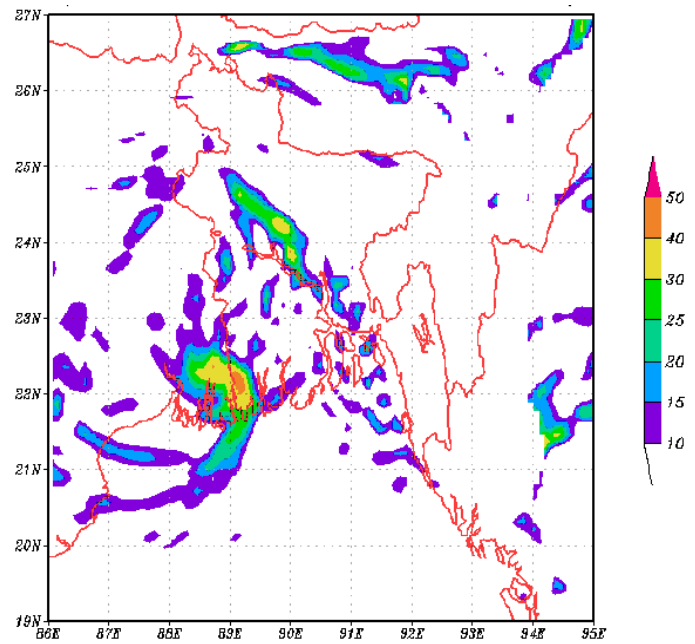

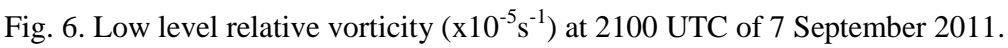

\section{(e) Low level convergence and upper level divergence}

The low level convergence and upper level divergence at 2100 UTC on 07 September 2011 are presented in Fig. 7(a-b). It is found that a well defined area of low level convergence extends from Bay of Bengal to central part of the country with a maxima over southeast Bangladesh [Fig. 7(a)]. The cutting across of the southerly low level winds (Fig. 3) and the convergence line is significant from the point of view of severe convective activity. A well defined area of the upper level divergence noticeable in the divergence field (Fig.7(b)) which is associated with the out flow of the upper level wind chart (Fig.4(b)).
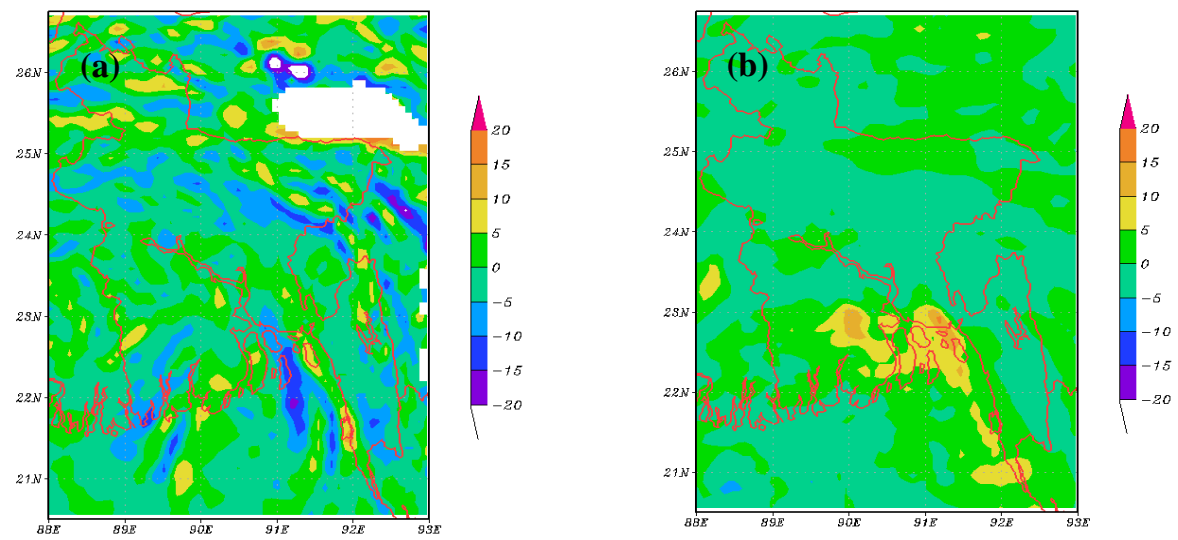

Fig. 7. Low level convergence and upper level divergence field valid at 2100 UTC on 7 September 2011. 


\section{(f) Outgoing longwave radiation}

The model derived outgoing longwave radiation (OLR) valid for 2100 UTC, 07 September 2011 is shown in the Fig. 8. It is found that the study area is characterized by low OLR of the order of $200 \mathrm{Wm}^{-2}$. It is evident that the dense convective clouds are characterized over the southeast region of Bangladesh (Fig.11(a-d)).

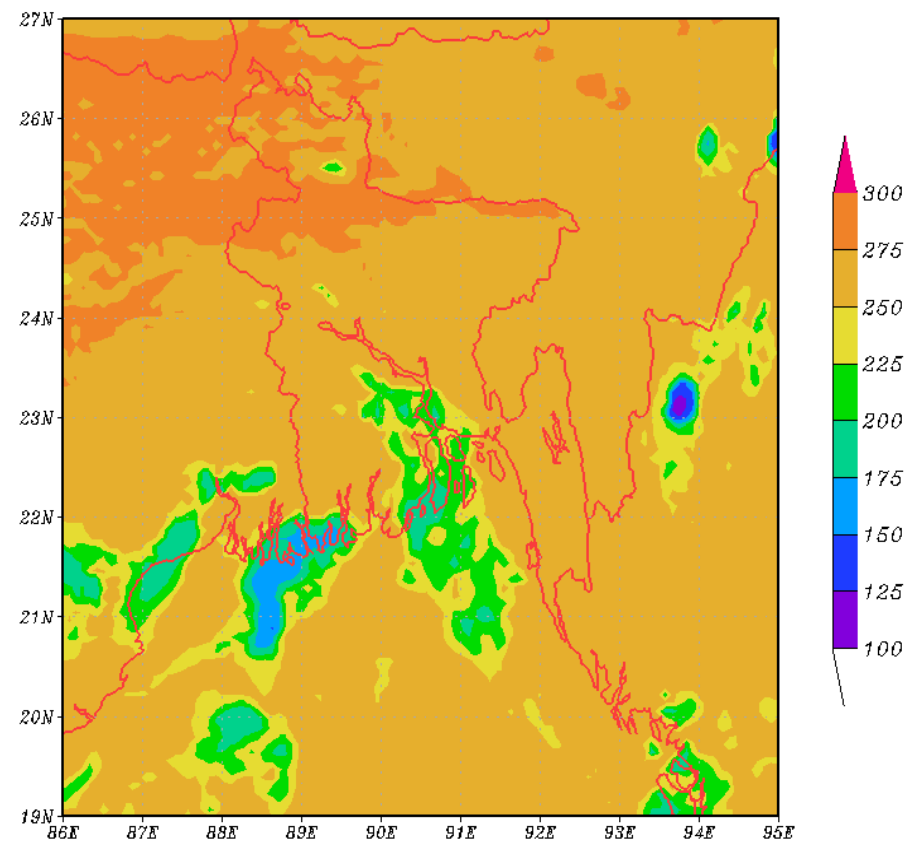

Fig. 8. Model simulated outgoing longwave radiation (OLR) valid for 2100 UTC, 7 September 2011.

\section{(g) Convective available potential energy $(\mathrm{CAPE})$ and convective inhibition energy (CINE)}

The distribution of model derived CAPE and CINE at 2100 UTC on 7 September 2011 are presented in the Fig. 9(a-b). The high values of CAPE ranging from 2000-3000 Jkg-1 are seen over the south, southeast Bangladesh and neighbourhoods with a maximum in the range of 2200-2400 $\mathrm{Jkg}^{-1}$. The CINE field over south, southeast region of Bangladesh has very low values. A combination of high CAPE and low CINE would render the environment thermodynamically favourable for convection. 

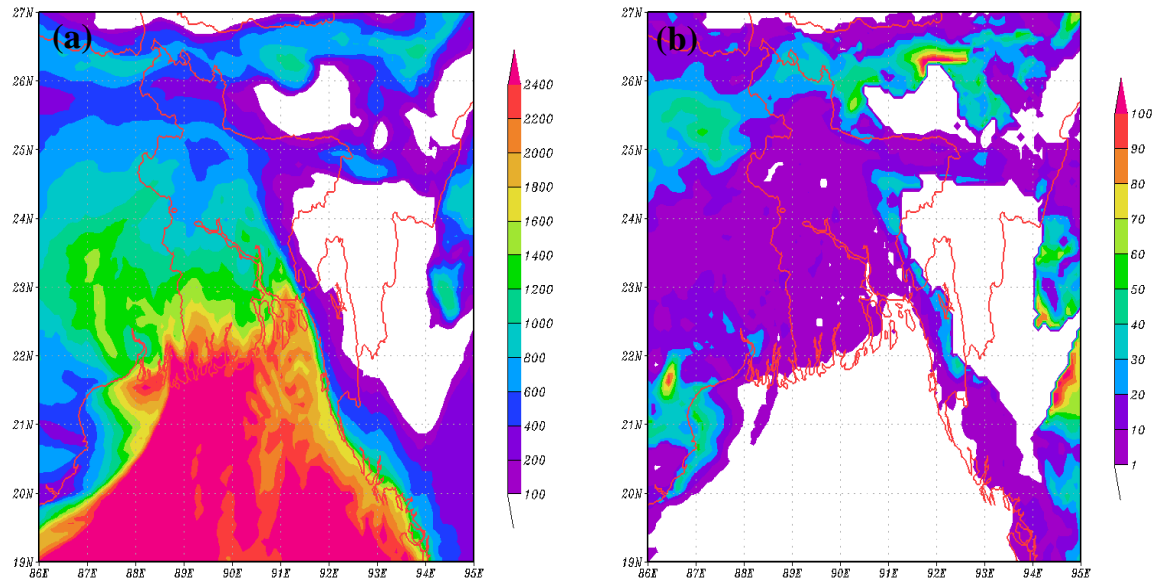

Fig. 9. Distribution of model derived CAPE (a) and CINE (b) valid for 2100 UTC of 7 September 2011.

\section{(h) Horizontal and vertical profile of relative humidity}

That the southerly low level flow is causing a heavy incursion of moisture into Bangladesh can be seen in Fig. 3(a), which contains the analyzed relative humidity field. A prominent tongue of high moisture, of magnitude about 90-100\%, extending from the head Bay of Bengal into central Bangladesh is an outstanding feature of this map (Fig.10(a)). A narrow zone of steep moisture gradient just southeast point of Bangladesh over the study area.
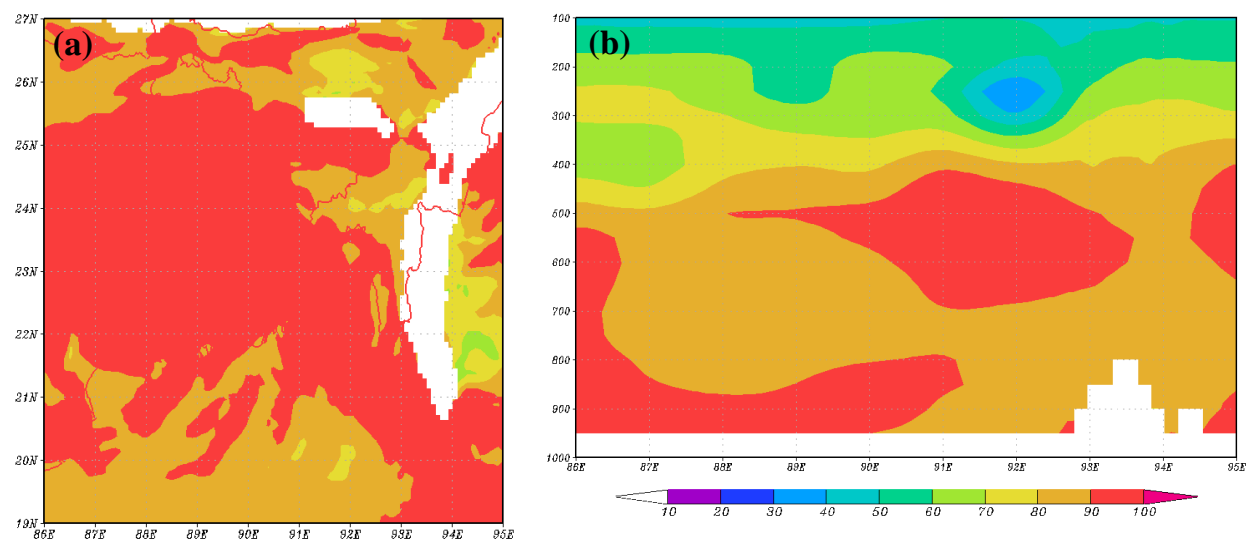

Fig. 10. Relative humidity analysis at $925 \mathrm{hPa}$ level (a) and vertical profile of relative humidity along the latitude of $23.78^{\circ} \mathrm{N}$ (b) valid for 2100 UTC of 7 September 2011.

The vertical profile of relative humidity valid at 2100 UTC on 07 September 2011 is shown in Fig.10(b). It is found that the high amount of moisture in the order of $90-100 \%$ 
extends upto $400 \mathrm{hPa}$ of the troposphere. Usually, this type of high moisture does not extend beyond $500 \mathrm{hPa}$ level during summer monsoon due to presence strong wind shear in the troposphere.

The meteosat cloud imageries are presented in the Fig. 11(a-d). The deep convective clouds are observed over the south, southeast coastal region of Bangladesh and neighbourhoods which are associated with the presence of outgoing longwave radiation (Fig. 8).

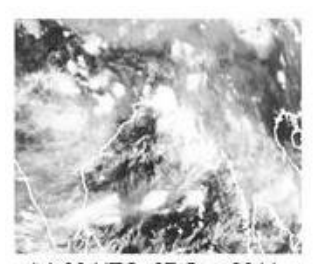

(a) 00 UTC, $07 \mathrm{Sep}, 2011$

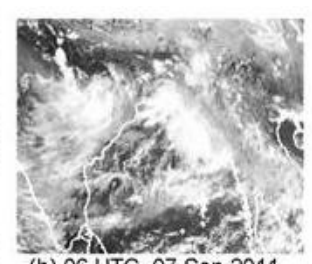

(b) 06 UTC, $07 \operatorname{Sep}, 2011$

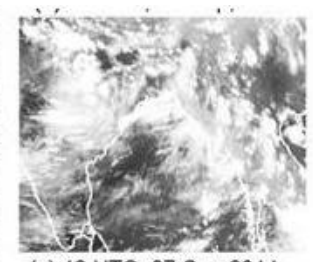

(c) 12 UTC, $07 \operatorname{Sep}, 2011$

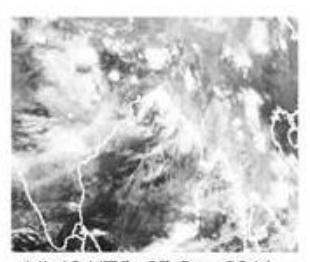

(d) 18 UTC, 07 Sep, 2011

Fig 11. Meterosat cloud imageries on 7 September 2011 at 0000 UTC (a), 0600 UTC (b), 1200 UTC (c), 1800 UTC (d).

\section{(i) Rainfall}

Model simulated 24-h accumulated rainfall valid for 7 September 2011 (a) was compared with that of TRMM 3B42RT (b) and BMD observed rainfall (c) which are presented in Fig. 12(a-c). It is found that the model has captured the rainfall pattern over the south, southeast coastal region of Bangladesh though there are some spatial biases in the simulated rainfall pattern.. It is seen that the first cell $\left(22.75^{\circ} \mathrm{N}, 90.37^{\circ} \mathrm{E}\right)$ is displaced 160 and $116 \mathrm{~km}$ and second cell $\left(21.98^{\circ} \mathrm{N}, 90.23^{\circ} \mathrm{E}\right)$ is displaced 132 and 85 $\mathrm{km}$ respectively.
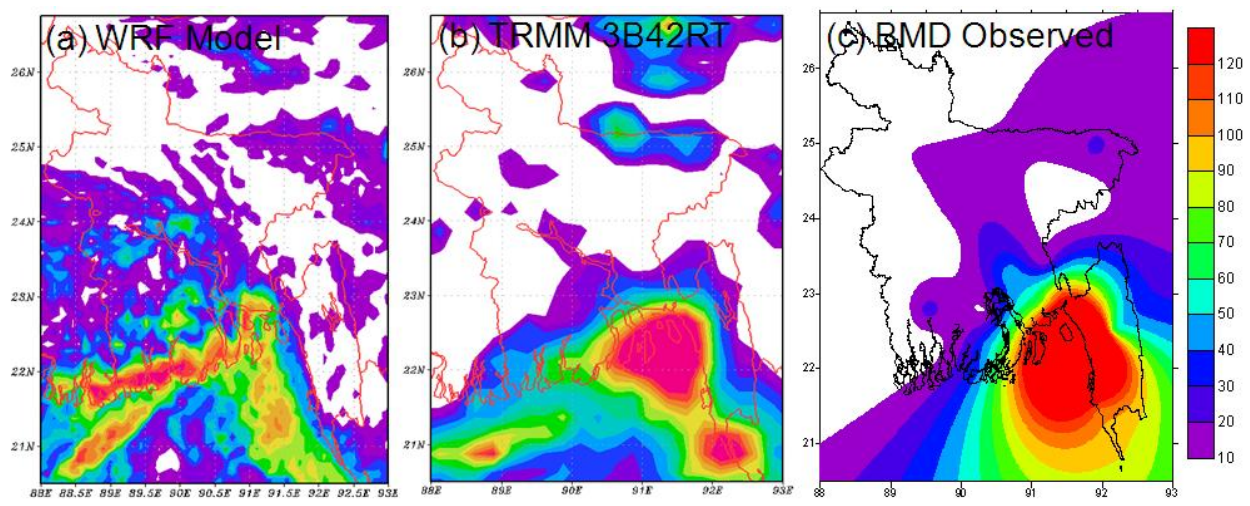

Fig.12. 24-h accumulated rainfall (a) Model (b) TRMM 3B42RT and (c) BMD observed rainfall 
The model simulated rainfall is further compared quantitatively with that of TRMM and BMD OBS which are presented in the Fig.13. For the quantitative comparison, the area average rainfall were calculated for the region $19.00-23.50^{\circ} \mathrm{N}$ and $88.00-93.00^{\circ} \mathrm{E}$ from Model and TRMM. The country average rainfall was calculated from the available stations within the region $19.00-23.50^{\circ} \mathrm{N}$ and $88.00-93.00^{\circ} \mathrm{E}$ from BMD observed rainfall. It is found that the model simulated rainfall under-predict the TRMM and BMD OBS. Model simulated rainfall found to be $6.52 \%$ and $41.10 \%$ lower than TRMM and BMD OBS rainfall, respectively.

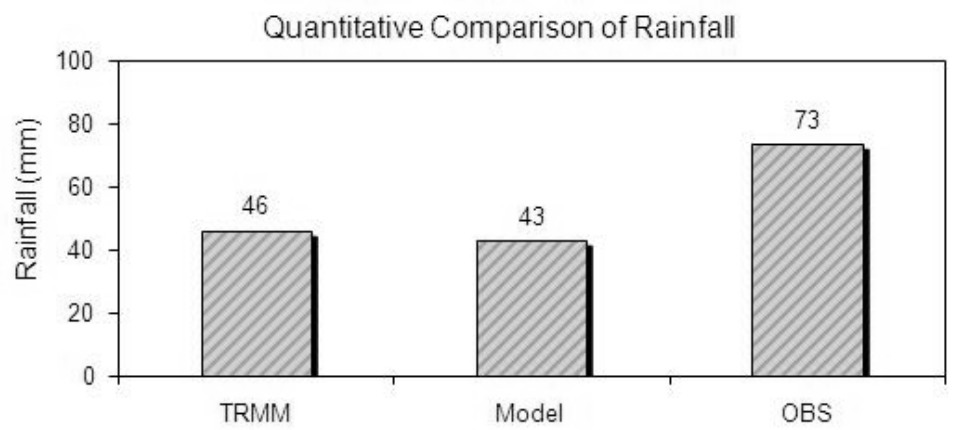

Fig. 13. Quantitative comparison of area average $\left(19.00-23.50^{\circ} \mathrm{N}\right.$ and $\left.88.00-93.00^{\circ} \mathrm{E}\right)$ model simulated rainfall with TRMM and BMD OBS.

\section{Conclusions}

On the basis of the present study, the following conclusions can be drawn:

1) A cyclonic circulation persisted at mean sea level over the Gangetic West Bengal and adjoining Bangladesh and Bay of Bengal.

2) The low level wind field shows that there was southwesterly flow from the Bay of Bengal towards the southeast coast of Bangladesh which converged over the south, southeast region of Bangladesh.

3) The strong southwesterly flow helped to transport high amount of moisture from the Bay of Bengal towards the south, southeast region of Bangladesh and neighbourhood.

The strong low level convergence helped to carry moisture up to $400 \mathrm{hPa}$ level and accordingly high relative humidity extended up to this level.

4) Model captured the heavy rainfall event over southeast region of Bangladesh reasonably well but there are some spatial and temporal biases in the simulated rainfall pattern.

Simulated rainfall amount was $6.52 \%$ and $41.10 \%$ lower than TRMM and BMD recorded rainfall, respectively. 
5) The south, southeast region of Bangladesh are characterized by strong low level vertical wind shear, high relative vorticity, low level convergence, upper level divergence, High CAPE and low CINE field.

6) There was the signature of low OLR over south, southeast region of Bangladesh.

7) WRF model suggests that this heavy rainfall event over south, southeast region of Bangladesh might be the result of an interaction of large scale monsoon flow with cyclonic circulation.

Finally, it may be concluded that the WRF Model (Version 3.2.1, Release August 2010) might be able to simulate the heavy rainfall event over southeast region of Bangladesh and associated synoptic features reasonably well, though there are some spatial and temporal biases in the simulated rainfall pattern.

Further study is required to understand more about such cases, data assimilation may be one of the possible solutions.

\section{Acknowledgements}

The authors would like to thank Ms Arjumand Habib, Director of SMRC and BMD for providing all the necessary facilities to carry out this research work.

\section{References}

1. Bangladesh Bureau of Statistics (BBS), The People's Republic of Bangladesh (2010).

2. K. Prasad, SMRC Scientific Report No. 11 (2005).

3. Climate Diagnostic Bulletin (CDB), India Meteorological Department (IMD), (2011).

4. Bangladesh Meteorological Department (BMD), Ministry of Defence, The People's Republic of Bangladesh (2011).

5. A. D. Charles, Proc. Intern. workshop on observation/forecasting of meso-scale weather and technology of reduction of relevant disasters (22-26 February 1993, Tokyo, Japan) pp. 181188.

6. M. N. Ahasan, M. A. M. Chowdhury, and D. A. Quadir, J. Sci. Res., 3 (2), 261 (2011). http://dx.doi.org/10.3329/jsr.v3i2.6656

7. A. Kumer, J. Dhdhia, R. Rotunno, N. Dev, and U. C. Mohanty, Q. J. R. Meteorol. Soc. 134, 1897 (2008). http://dx.doi.org/10.1002/qi.325

8. S. K. Dev, C. M. Kishtawal, V. S. Bongirwar, and P. K. Pal, Nat. Hazard 52, 117 (2010). http://dx.doi.org/10.1007/s11069-009-9361-8

9. P. K. Patra, M. S. Santhanam, K. V. J. Potty, M. T. Tewari, and P. L. S. Rao, Curr. Sci. 79, 70 (2000).

10. S. Das, SMRC Scientific Report No. 28, 45 pp (2009).

11. S. Das, SMRC Scientific Report No. 35, 62 pp (2010).

12. A, J. Litta, B. Chakrapani and K. Mohnakumer, Meteorol. Appl. 14, 291 (2007).

13. S. Das, M. Rahman, and J. Singh, SMRC Scientific Report No. 42, 38 pp (2012).

14. M. N. Ahasan, M. A. M. Chowdhury \& D. A. Quadir, J. Hydrol. Meteorol. 7 (1), 1 (2010).

15. J. S. Kain, J. Appl. Meteor. 43, 170 (2004). http://dx.doi.org/10.1175/1520-0450(2004)043<0170:TKCPAU>2.0.CO;2

16. S. Y. Hong and J. Dudhia, Proc. of the $16^{\text {th }}$ conference on numerical weather prediction, Seattle, WA (2003).

17. E. J. Mlawer, S. J. Taubman, P. D. Brown, M. J. Iacono, and S. A. Clough, J. Geophys. Res. 102 (D14), 16663-16682 (1997). http://dx.doi.org/10.1029/97JD00237 
434 Synoptic Analysis

18. J. Dudhia, J. Atmos. Sci. 46, 3077 (1989).

http://dx.doi.org/10.1175/1520-0469(1989)046<3077:NSOCOD>2.0.CO;2

19. See, http://ake.nascom.nasa.gov/ 